\title{
Strategi Menghindarkan Indonesia dari Ancaman Resesi Ekonomi di Masa Pandemi
}

\author{
Selena Riri Blandina ${ }^{1}$, Alvin Noor Fitrian², Wulan Septiyani ${ }^{3}$ \\ selenablandina@gmail.com¹, alvinnoorf@gmail.com², septiyaniwulann@gmail.com³ \\ Program Studi Akuntansi, Fakultas Ekonomi dan Bisnis 1,3 \\ Program Studi Teknik Industri, Fakultas Teknik Industri2 \\ Universitas Pembangunan Nasional Veteran Yogyakarta1,2,3
}

\begin{abstract}
The Covid-19 pandemic has hit the world, especially the State of Indonesia. The Covid-19 pandemic not only had an impact on increasing casualties but also had a broad and direct impact on the decline in the world economy. Data from the Central Statistics Agency reported that Indonesia's economic growth contracted by $5.32 \%$ in the second quarter of 2020 . Then in the first quarter, it contracted by $6.13 \%$, which was the worst record for the economy since 1999. Predictions that the global economy will enter a recession that very sharp until the end of the first quarter of 2020 has been informed by the International Monetary Fund and the World Bank. This study aims to analyze strategies that can be taken by Indonesia in facing the threat of an economic recession. The research method used is descriptive qualitative, where the data is obtained from an in-depth, analyzed literature study. The results of this study obtained strategies for the Indonesian government to face the threat of recession, including the government's fiscal and monetary capabilities, productivity improvements, competitiveness; investigation; and the world economy. In addition to the role of the government, the community also has a role to play, such as developing startup business innovations and supporting UMKM business players in an effort to encourage economic growth to keep going amid the economic crisis caused by the Covid-19 outbreak.
\end{abstract}

Keywords: economy, pandemic, recession

\begin{abstract}
Abstrak
Pandemi Covid-19 telah melanda dunia khususnya Negara Indonesia. Pandemi Covid-19 tidak hanya berdampak pada peningkatan korban jiwa, tetapi juga berdampak luas dan langsung terhadap penurunan perekonomian dunia. Data dari Badan Pusat Statistik melaporkan pertumbuhan ekonomi Indonesia mengalami kontraksi sebesar $5,32 \%$ pada triwulan II tahun 2020. Kemudian pada triwulan pertama mengalami kontraksi sebesar $6,13 \%$ yang merupakan rekor terburuk perekonomian sejak tahun 1999. Prediksi bahwa ekonomi global akan memasuki resesi yang sangat tajam hingga akhir kuartal I tahun 2020 telah diinformasikan oleh International Monetery Fund dan World Bank. Penelitian ini bertujuan untuk menganalisis strategi-strategi yang dapat ditempuh oleh Indonesia dalam menghadapi ancaman resesi ekonomi. Metode penelitian yang digunakan adalah kualitatif deskriptif, dimana data-data diperoleh dari studi literatur yang dianalisis mendalam. Hasil kajian ini diperoleh strategi bagi pemerintah Indonesia untuk menghadapi ancaman resesi antara lain kemampuan fiskal dan moneter pemerintah; perbaikan produktivitas; daya saing; investasi; dan perekonomian dunia. Selain peran pemerintah, masyarakat juga memiliki peran untuk seperti melakukan pengembangan inovasi bisnis startup dan mendukung para pelaku usaha UMKM sebagai upaya mendorong pertumbuhan ekonomi agar tetap berjalan di tengah krisis ekonomi akibat wabah Covid-19.
\end{abstract}

Kata Kunci: ekonomi, pandemi, resesi 


\section{PENDAHULUAN}

Organisasi World Health Organization (WHO) pada tanggal 11 Maret 2020 menyatakan bahwa dunia sedang mengalami Global Pandemic Corona Virus Disease-19 (Covid-19) sejak awal tahun 2020. Covid-19 pertama kali ditemukan di Indonesia pada tanggal 2 Maret 2020 (Moedjiono, 2020). Seiring berjalannya waktu, Covid-19 semakin meluas di seluruh wilayah Indonesia. Dikutip dari laman detiknews, sejak 2 Maret hingga 21 April 2020 kasus Covid-19 di Indonesia mencapai 7.135 kasus (Tim Infografis, 2020). Peningkatan kasus Covid-19 tidak hanya sampai April namun terus berkembang hingga puncaknya terjadi pada bulan Mei dan Juni 2020 (Kompas.com, 2020). Pandemi yang terjadi di seluruh wilayah Indonesia ini membuat pemerintah sangat perlu memberlakukan suatu kebijakan untuk menekan laju pertumbuhan Covid-19. Salah satu cara yang dipilih pemerintah yaitu melakukan Pembatasan Sosial Berskala Besar (PSBB). Pembatasan ini telah diterapkan hampir di semua wilayah, terutama di pusat-putat kegiatan sosial kemasyarakatan. Wabah ini mempengaruhi berbagai sektor kehidupan terutama sektor ekonomi. Penerapan PSBB di berbagai wilayah menimbulkan banyak permasalahan baru yang harus dihadapi oleh masyarakat.

PSBB membuat proses ekspor dan impor tidak dapat berjalan semestinya sehingga memperlambat laju investasi dalam negeri (Mahera \& Nurwati, 2020). Selain itu, banyak karyawan yang dirumahkan akibat larangan pemerintah untuk membuat kerumunan dalam jumlah besar. Pemutusan Hubungan Kerja (PHK) masal ini juga sebagai akibat dari turunnya omset perusahaan karena menurunnya jumlah permintaan akan suatu produk tertentu (Mahera \& Nurwati, 2020). Andry Satrio Nugroho mengatakan juga bahwa gelombang PHK yang lebih besar akan datang pada akhir kuartal II-2020 (Kompas.com, 2020). Hal ini terkonfirmasi berdasarkan keterangan Kementerian Ketenagakerjaan Juni 2020 bahwa jumlah karyawan yang dirumahkan sebanyak 3,05 juta sejak Maret 2020 (Kompas.com, 2020).

Tidak hanya pada perusahaan besar saja, UMKM juga mengalami kemerosotan (Liputan6.com, 2020). Menteri Keuangan Sri Mulyani mengatakan pandemi ini setidaknya mengakibatkan tiga dampak besar diantaranya, menurunnya daya beli masyarakat, melemahnya tingkat investasi, dan berhentinya proses ekspor ke seluruh negara (Liputan6.com, 2020). Dalam penelitian yang dilakukan oleh Mahera \& Nurwati (2020) menyatakan bahwa meskipun Indonesia sedang mengalami keterpurukan ekonomi nasional, Usaha Mikro, Kecil, Menengah (UMKM) dipercaya memiliki peranan penting sebagai pilar dan penyangga yang dapat menyelamatkan perekonomian Indonesia. Mahera \& Nurwati (2020) dalam penelitiannya menyebutkan bahwa Indonesia dikhawatirkan akan mengalami krisis ekonomi pada akhir tahun 2020 untuk ketiga kalinya sejak tahun 1998.

International Monetary Fund dan World Bank memprediksi bahwa resesi akan mengancam perekonomian global hingga akhir kuartal I tahun 2020 (Nasution et al., 2020). Berdasarkan kondisi tersebut, peneliti tertarik untuk meneliti dan menganalisi tentang strategi yang dapat dilakukan oleh pemerintah dan masyarakat untuk menghindarkan Indonesia dari resesi ekonomi di masa pandemi. 
Resesi adalah kondisi dimana pertumbuhan ekonomi riil tumbuh negative atau dengan kata lain terjadi penurunan produk domestik bruto selama dua kuartal berturut-turut dalam satu tahun berjalan. Resesi ditandai dengan melemahnya perekonomian global dan akan mempengaruhi ekonomi domestik negara-negara di seluruh dunia. Kemungkinan suatu negara mengalami resesi semakin kuat apabila perekonomian negara tersebut memiliki ketergantungan pada perekonomian global (Miraza, 2019). Resesi ekonomi dapat menyebabkan terjadinya penurunan semua aktivitas ekonomi seperti keuntungan perusahaan, lapangan kerja dan investasi secara bersaman. Resesi ekonomi biasanya terkait dengan adanya penurunan harga (deflasi), atau sebaliknya, kenaikan harga yang tajam (inflasi) dalam proses yang disebut stagflasi. Faktor-faktor lain terjadinya resesi dapat dilihat dari beberapa hal seperti ketidakseimbangan antara produksi dan konsumsi, pertumbuhan ekonomi yang lambat atau menurun selama dua kuartal berturut-turut, nilai impor jauh lebih besar dibandingan nilai ekspor, dan tingkat pengangguran yang semakin tinggi.

\section{METODE PENELITIAN}

Penelitian ini menggunakan metode kualitatif deskriptif berdasarkan studi literatur dan analisis yang mendalam. Penelitian kualitatif merupakan metode yang digunakan untuk memahami fenomena yang dialami oleh subjek penelitian dengan mendeskripsikan dalam bentuk bahasa, kata-kata, dan konteks khusus yang alamiah (Sugiyono, 2014). Studi literatur diantaranya berasal dari jurnal nasional dan internasional yang relevan, sumber laman terpercaya, serta beberapa artikel yang dipublikasikan secara online. Ruang lingkup penelitian ini terfokus pada masalah perekonomian Indonesia selama masa pandemi. Tujuan dari penelitian ini yaitu menghindarkan Indonesia dari ancaman resesi ekonomi yang ditempuh dengan cara menyusun strategi-strategi yang dapat dilakukan baik oleh pemerintah dan masyarakat terkait. Analisis data dilakukan dengan cara merepresentasikan data yang diperoleh dengan literatur yang dirujuk untuk memetakan strategi yang relevan.

\section{HASIL DAN PEMBAHASAN}

Berbagai belahan dunia dalam pengalamannya telah menunjukan bahwa pemerintah memiliki peran yang sangat penting dalam memperbaiki ekonomi pada fase penyebaran pandemi Covid-19 (Faroni et al., 2020). Berbagai paket kebijakan sekaligus stimulus ekonomi diinisiasi oleh pemerintah seperti memberikan relaksasi terhadap beberapa aktivitas ekonomi dalam usaha peningkatan penerimaan negara seperti jaminan sosial, penundaan pembayaran pinjaman dan pajak serta bantuan negara terus dilaksanakan. Konsekuensi ini timbul dari adanya krisis ekonomi dunia terkait pandemi yang memicu peningkatan peran serta intervensi negara atau pemerintah, masyarakat dan lembaga keuangan baik nasional maupun internasional (Sulkowski, 2020).

Berdasarkan data yang diperoleh dari (Badan Pusat Statistik, 2020), Produk Domestik Bruto (PDB) Indonesia pada Q1-2020 tercatat hanya tumbuh sebesar 2,97\% (y-0-y) yang merupakan angka pertumbuhan terendah sejak 2001. Disamping itu, ekonomi Indonesia Q22020 terhadap Q2-2019 mengalami kontraksi pertumbuhan sebesar 5,32\% (y-0-y). Kontraksi pertumbuhan terjadi di hampir semua wilayah usaha. Bidang usaha yang mengalami kontraksi pertumbuhan yang signifikan yaitu industry transportasi dan penyimpanan (pergudangan) yang 
mengalami peningkatan sebesar 30,84\%; dan Penyediaan Akomodasi dan Makan Minum sebesar 22,02\%. Menurut sumber pertumbuhan ekonomi Indonesia Q2-2020 (y-on-y), Lapangan Usaha Informasi menunjukan pertumbuhan tertinggi yaitu sebesar $0,58 \%$; kemudian disusul Perikanan, Pertanian dan Kehutanan sebesar 0,29\%; dan Real Estat sebesar 0,07\%.

Pesatnya perkembangan teknologi telah mengubah tatanan ekonomi global bergerak menuju ekonomi digital dan perkembangan keuangan. Apalagi dalam masa pandemi Covid-19 transaksi online terus berkembang pesat akibat adanya kebijakan work from home (WFH) dan Pembatasan Sosial Berskala Besar (PSBB) yang ditetapkan (E.P Saputro, 2020). Digitalisasi ekonomi merupakan langkah bagi pelaku ekonomi agar dapat mempertahankan usahanya dalam menghadapi kondisi pandemi sekaligus merupakan peluang besar yang digunakan untuk menghindarkan Indonesia dari resesi ekonomi (Kautsar \& Krisnadi, 2020). Contoh lain yang dapat dikembangkan oleh pemerintah yaitu dengan menumbuhkembangkan jenis usaha yang bergerak di bidang startup. Bisnis startup secara global saat ini sedang mengalami peningkatan jumlah permintaan dan penggunaan. Meskipun tidak sedikit juga bisnis startup yang chaos selama masa pandemi, tapi beberapa diantaranya masih dapat bertahan bahkan mengalami peningkatan jumlah penggunaan. Selain pemerintah, masyarakat juga dapat turut serta aktif dalam pengembangan bisnis digital seperti melakukan magang di perusahaan startup di Indonesia untuk membantu memberikan ide dan inovasi terkait pengembangan bisnisnya. Selama masa pandemi mungkin banyak perusahaan manufaktur yang menutup akses untuk masuk ke perusahaan, namun berbeda dengan perusahaan startup yang tetap membuka akses magang bagi mahasiswa (khususnya tingkat akhir) dengan sistem Work From Home (WFH).

Pengembangan bisnis digital seperti yang terjadi di perusahaan startup tentu membutuhkan dana segar yang jumlahnya tidak sedikit. Dimasa pandemi seperti saat ini, perputaran uang di masyarakat menjadi tidak stabil. Beberapa memilih untuk mengalokasikan uang yang dimiliki hanya untuk kebutuhan pribadi, karena takut mengalami kerugian. Frekuensi pendanaan investasi di bidang startup sejak Januari 2019 hingga September 2020 dapat dilihat pada Gambar 1 (Salim, 2020). Berdasarkan diagram pada Gambar 1, E-commerce dan Fintech menempati dua urutan teratas dari jumlah investasi yang dialokasikan ke perusahaan startup. Dalam hal ini seharusnya pemerintah perlu memberikan perhatian khusus pada perusahaan startup atau yang berbasis ekonomi digital karena bagaimanapun perusahaan tersebut masih dapat tetap bersaing sehingga dapat dikategorikan sebagai perusahaan bonafit (Feranika \& Haryati, 2020). 
Efektor, Volume 7 Issue 2, 2020, Pages 181-190

Selena Riri Blandina, Alvin Noor Fitrian, Wulan Septiyani

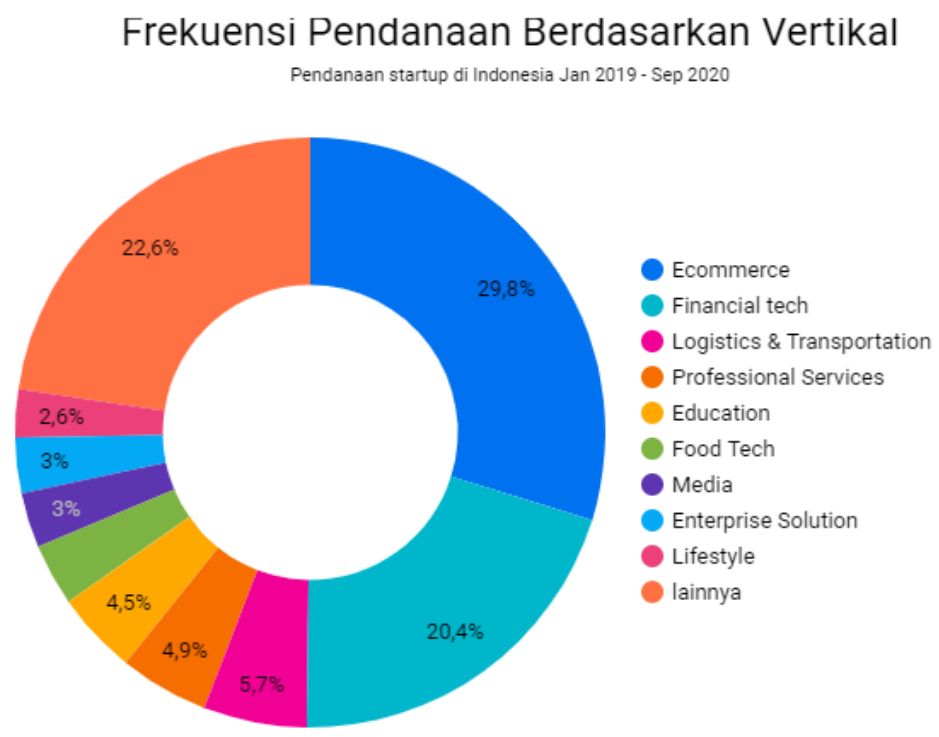

Gambar 1. Jumlah pendanaan investasi di bidang startup sejak Januari 2019 hingga September 2020

Sumber: Google Data Studio

Pada triwulan II tahun 2020, perekonomian Indonesia mengalami peningkatan sebesar 4,19\% (q-to-q) dibandingkan dengan triwulan sebelumnya. Pertumbuhan negatif terutama terjadi pada Ekspor Barang dan Jasa sebesar 11,66\%; diikuti Pembentukan Modal Tetap Bruto (PMTB) sebesar 8,61\%; dan Komponen PK-LNPRT sebesar 7,76\%. Lembaga Non-Profit yang Melayani Rumah Tangga (LNPRT) menunjukkan bahwa unit tersebut merupakan salah satu unit perekonomian nasional yang perlu diperhatikan. Selain itu, Badan Koordinasi Penanaman Modal (BKPM) menyatakan bahwa pelaku usaha mikro, kecil, dan menengah (UMKM) mendominasi jumlah investasi selama masa pandemi Covid-19.

Badan Pusat Statistik menyebutkan bahwa terdapat 64 juta Usaha Mikro Kecil dan Menengah (UMKM) dimana angka tersebut mencapai 99,9\% dari keseluruhan usaha yang beroperasi di Indonesia (Liputan6.com, 2020). Namun selama pandemi Covid-19 ini, sektor UMKM merupakan sektor yang paling terdampak. Banyak dari pengusaha tersebut yang harus gulung tikar karena permintaan jatuh dan tidak adanya transaksi ekonomi. Menurut UndangUndang Republik Indonesia Nomor 20 Tahun 2008 Tentang Usaha Mikro, Kecil, Dan Menengah, sektor UMKM merupakan salah satu sektor yang dapat memberikan kontribusi besar untuk meningkatkan pertumbuhan ekonomi nasional. Oleh karena itu, sektor UMKM harus diberdayakan agar dapat memperkokoh dan menopang sendi ekonomi Indonesia terutama dalam masa pandemi Covid-19 (Marlinah, 2020). Salah satu strategi yang dapat ditempuh oleh masyarakat sebagai konsumen yaitu dengan membeli atau bertransaksi pada UMKM. Dengan membeli produk-produk hasil UMKM, maka masyarakat juga dapat menjadi seorang pahlawan yang ikut berkontribusi menjaga kelangsungan hidup UMKM dan mendorong perekonomian bangsa di masa pandemi Covid-19 (Nafiah et al., 2020).

BPKM juga menjelaskan, selama masa pandemi, UMKM di sektor makanan dan alat kesehatan paling banyak mengajukan izin operasional komersial (IOK). Hal ini dapat disimpulkan pula bahwa pandemi yang terjadi juga memaksa masyarakat untuk terus bertahan, 
salah satunya yaitu dengan membuka UMKM. Kementerian Koperasi dan UKM dibantu Kementerian Perekonomian dan Kementerian Ketenagakerjaan harus turut aktif memberikan kemudahan khususnya dalam memberikan izin untuk membuka usaha. Otoritas Jasa Keuangan (OJK) juga selain memilah pengajuan pendirian usaha juga harus memberikan treatment bagi usaha yang dinilai dapat memberikan keuntungan bagi perekonomian nasional.

Sektor tenaga kerja baik formal maupun informal ikut terpengaruh dalam dampak Covid-19. Menurut data Kementerian Ketenagakerjaan per 20 April 2020 menyatakan bahwa jumlah sektor formal yang terdampak sebanyak 84.926 perusahaan dan 1.546 .208 pekerja. Sedangkan untuk sektor informal perusahaan yang terdampak sejumlah 31.444 dan jumlah karyawan yang ter-PHK sejumlah 538.385. Dampak tersebut salah satunya disebabkan karena pemberlakuan Work From Home (WFH) dan sistem lockdown diberbagai wilayah sehingga kebanyakan perusahaan akan mengurangi jumlah karyawan. Data terakhir Badan Pusat Statistik (BPS) pada Agustus 2019 menunjukkan tingkat pengangguran terbuka mencapai 7,05 juta atau 5,28\% dari total angkatan kerja. Center for Economic Reform (CORE) memperkirakan pada triwulan II tahun 2020 jumlah pengangguran terbuka akan meningkat sebesar 4,25 juta. Angka tersebut merupakan prediksi yang dibuat oleh INTI berdasarkan skenario ringan yang terkena pandemi corona. Di saat yang sama, 6,68 juta orang akan menganggur dalam kondisi sedang dan 9,35 juta dalam kondisi parah.

Pemerintah telah mengembangkan berbagai program jaring pengaman sosial untuk memitigasi dampak pandemi COVID-19 (terutama pengangguran) salah satu program tersebut yaitu "Kartu Pra Kerja". Program tersebut bertujuan untuk membantu 5,6 juta orang di Indonesia yang menganggur dengan meningkatkan anggaran dari $\mathrm{Rp} 10$ triliun menjadi $\mathrm{Rp} 20$ triliun. Awalnya program tersebut hanya ditujukan untuk masyarakat yang terkena dampak PHK akibat Covid-19. Namun pada kenyataannya semua pengangguran termasuk mereka yang baru menyelesaikan pendidikan formal ikut berpartisipasi. Antusiasme masyarakat meningkat derastis ketika pendaftaran dibuka, kurang lebih 23,8 juta orang pendaftar dan penerima Kartu Pra Kerja. Dengan adanya antusiasme dan sasaran yang tidak spesifik pemerintah saat ini sudah membuka pendaftaran hingga gelombang ke sepuluh.

Ketika pandemi COVID-19 memperlambat perekonomian global, pemerintah telah melakukan beberapa langkah untuk mendorong pertumbuhan ekonomi domestik salah satunya yaitu melakukan penurunan atas BI 7-Day Reverse Repo Rate sebesar 25 bps menjadi 4.75\%, suku bunga Deposit Facility sebesar 25 bps menjadi 4.00\% dan suku bunga Lending Facility sebesar 25 bps menjadi 5.50\%. Upaya pengendalian inflasi dan stabilitas eksternal juga harus dilakukan dengan cara memantau perkembangan ekonomi global dan domestik untuk mendorong peningkatan pertumbuhan ekonomi (Nasution et al., 2020).

Pada saat ekonomi berjalan terlalu lambat yang ditandai dengan tingginya tingkat pengangguran, rendahnya pertumbuhan perekonomian negara maka kebijakan yang dapat diambil oleh pemerintah untuk mendorong pertumbuhan perekonomian lebih cepat dan pengangguran dapat ditekan yaitu dengan mengeluarkan kebijakan fiskal dan kebijakan moneter (Ada Tua, 2019 dalam Ayu \& Haryati, 2020). Pengelolaan kebijakan fiskal dan moneter 
dalam yang sinergis akan memberikan dampak positif dan menjaga stabilitas ekonomi di masa pandemi dalam menghadapi ancaman resesi (A. O'Sullivan, 2003).

Kebijakan fiskal berpengaruh secara signifikan terhadap produktivitas pelaku UKM melalui Keberhasilan penanganan Covid-19 (Feranika \& Haryati, 2020). Melalui kebijakan fiskal pemerintah melakukan refocusing kegiatan dan realokasi anggaran. Dalam jangka pendek kebijakan tersebut harus difokuskan pada pemberian bantuan darurat kepada populasi yang rentan dan bisnis yang terkena dampak. Pemerintah menggunakan kebijakan fiskal untuk memperbaiki perekonomian negara akibat Covid-19 diantaranya:

1. Paket stimulus pertama USD 725 juta Februari 2020 yang dialokasikan untuk mendukung industri pariwisata, penerbangan dan properti. Stimulus ini juga dialokasikan untuk rumah tangga berpenghasilan rendah sebanyak USD 324 juta.

2. Paket stimulus kedua USD 8,1 miliar dialokasikan untuk pembebasan pajak penghasilan beberapa pekerja di bidang manufaktur dan memberikan diskon atas pembayaran pajak perusahaan manufaktur.

3. Paket stimulus ketiga USD 24,5 miliar dialokasikan untuk perawatan kesehatan, perlindungan sosial dan insentif pajak. Stimulus ini bertujuan untuk meningkatkan manfaat dan cakupan yang lebih luas dari bantuan sosial yang ada untuk rumah tangga berpenghasilan rendah, seperti bantuan pangan, transfer tunai bersyarat dan subsidi listrik, dan tunjangan pengangguran yang diperluas.

4. Pada 18 Mei 2020 stimulus ekonomi USD 43 miliar dialokasikan untuk mendukung 12 perusahaan milik negara, dilanjutkan dengan pemberian subsidi pada pembayaran kembali pinjaman sekitar 60 juta peminjam dan program penguatan jaring pengaman sosial.

5. Kebijakan keringanan dan pembebasan pajak serta percepatan pengembalian PPN.

6. Pemotongan pembayaran pajak perusahaan dari $25 \%$ tahun 2020 menjadi $22 \%$ pada tahun 2021 dan 20\% untuk tahun keuangan 2022 dan seterusnya.

7. Paket stimulus fiskal sebesar USD 75,7 miliar dengan alokasi dukungan pendapatan langsung sebesar USD 67,6 miliar.

Selain itu, realokasi anggaran dilakukan untuk membentuk Anggaran Pendanaan penanganan epidemic Covid-19 diantaranya pengeluaran untuk tidak mendesak barang dan belanja modal yang bukan aproprioritas dan belum direncanakan (Hasibuan et al., 2020). Menurut Naryono (2020), pemerintah Indonesia menggunakan dana dari anggaran tersebut untuk merealisasikan beberapa cara atau strategi untuk; 1) Peningkatan daya jual masyarakat; 2) Peningkatan fokus pemerintah pada ekonomi mikro; 3) Stabilitas Nilai Tukar Rupiah yang harus selalu dijaga; 4) Pemberian relaksasi dan insentif kepada masyarakat dalam rangka perputaran roda ekonomi; 5) Pengurangan angka pengangguran; 6) Kapasitas kualitas edukasi kesehatan masyarakat.

Pendekatan-pendekatan tersebut diambil oleh Pemerintah Indonesia karena merupakan langkah krusial dalam menghadapi ancaman resesi dari pandemi Covid-19 (Kautsar \& Krisnadi, 
2020). Pemerintah Indonesia telah menetapkan berbagai strategi kebijakan perpajakan selama pandemi Covid-19 yang bertujuan untuk mencapat target penerimaan negara yaitu dengan merevisi target penerimaan perpajakan dan mere-alokasi penerimaan negara dalam Anggaran Pendapatan dan Belanja Negara tahun 2020 (Aulawi, 2020). Pemerintah juga telah melonggarkan pengenaan PPh Pasal 21, PPh Pasal 22, PPh Pasal 25, dan SPT khusus PPN sektor manufaktur. Sehingga pelonggaran pajak penghasilan pada pasal 21, 22 dan 25 serta SPT merupakan cara yang paling efektif dan tepat untuk mengatasi dampak perekonomian Indonesia dalam menghadapi wabah Covid-19.

Selain kebijakan fiskal, pemerintah juga menerapkan kebijakan moneter untuk mendorong investasi dalam meningkatkan perekonomian Indonesia. Kebijakan ini secara umum ditempuh oleh Bank Indonesia sebagai bank sentral untuk menjaga dan mencapai kestabilan mata uang. Penetapan tingkat suku bunga dan pengendalian jumlah uang beredar merupakan salah satu strategi yang digunakan untuk menstabilkan mata uang. Adapun langkah kebijakan moneter yang ditempuh oleh pemerintah yaitu sebagai berikut:

1. Tanggal 20 Februari Bank Indonesia memangkas suku bunga reverse repo 7 hari sebesar $25 \mathrm{bp}$ menjadi $4,75 \%$. Perusahaan juga memangkas suku bunga fasilitas simpanan menjadi $4 \%$ dan suku bunga fasilitas pinjaman menjadi $5,5 \%$.

2. Pada tanggal 2 Maret Bank Indonesia mengumumkan langkah-langkah untuk menstabilkan rupiah karena investor asing menjual aset keuangan Indonesia dari saham ke obligasi dan setelah Indonesia secara resmi melaporkan kasus COVID-19 pertamanya. Mereka untuk menstabilkan nilai tukar rupiah, meningkatkan likuiditas valuta asing dan memperluas cakupan transaksi yang mendasarinya untuk memberikan instrumen lindung nilai alternatif bagi investor asing.

3. Langkah kebijakan lainnya adalah dengan memperkuat strategi operasi moneter, menyesuaikan ketentuan rasio intermediasi makroprudensial, memperluas penerimaan QR Standar Indonesia dan mempercepat elektronifikasi dana bansos serta transaksi keuangan pemerintah daerah.

Pada Maret 2020, para menteri ASEAN yang bertanggung jawab atas ekonomi menyetujui tanggapan kolektif untuk mengurangi dampak ekonomi dari keadaan darurat COVID-19. Hal ini dilakukan untuk mengendalikan pasar ASEAN agar tetap terbuka untuk perdagangan dan investasi, meningkatkan berbagi informasi regional dan kolaborasi, menghindari tindakan yang dapat memicu tekanan inflasi atau berdampak buruk pada ketahanan pangan regional serta membangun kepercayaan di Asia Tenggara sebagai pusat investasi, perdagangan, tujuan pariwisata, memanfaatkan teknologi dan perdagangan digital untuk mempromosikan pengembangan bisnis yang berkelanjutan dan meningkatkan ketahanan rantai pasokan jangka panjang. Meskipun wabah Covid-19 terus menebar ancaman, ada beberapa faktor yang membuat pelaku UMKM masih mampu sustainable ditengah wabah ini, salah satu di antaranya adalah masyarakat yang membeli produk-produk dari UMKM yang menghasilkan barang konsumsi dan bisnis kecil atau jasa yang selalu dekat dengan masyarakat. Hal ini membuktikan bahwa peran masyarakat juga tidak kalah penting untuk 
mendorong perekonomian negara dalam masa pandemi Covid-19 (Daud, 2020). Dengan berbagai strategi dan kebijakan yang dilakukan baik oleh masyarakat maupun pemerintah diharapkan dapat mencegah serta menghindarkan negara Indonesia dari resesi ekonomi di tengah pandemi Covid-19.

\section{SIMPULAN}

Dari hasil pembahasan dapat disimpulkan bahwa adanya Covid-19 membuat perekonomian dunia khususnya Indonesia terancam resesi. Melihat kondisi tersebut pemerintah Indonesia mengantisipasinya dengan membuat berbagai paket atau stimulus kebijakan yang memberikan kontribusi aktif untuk mendongkrak pertumbuhan ekonomi melalui kebijakan fiskal dan moneter pemerintah yang ditujukan untuk perbaikan produktivitas, daya saing, investasi serta pertumbuhan perekonomian dunia. Selain itu, diperlukan kontribusi dari masyarakat dengan cara mendukung usaha UMKM agar dapat bertahan di masa pandemi ini dengan membeli produk-produk UMKM tersebut dimana usaha UMKM merupakan salah satu sektor yang mencapai angka 99,9\% dari keseluruhan usaha yang beroperasi di Indonesia sehingga memberikan kontribusi besar untuk meningkatkan pertumbuhan ekonomi nasional. Masyarakat juga dapat memberikan inovasi atau perbaikan system informasi di bisnis startup yang sedang dikembangkan dalam rangka menumbuhkembangkan bisnis digital sebagai solusi mengatasi kelemahan ekonomi akibat pandemi Covid-19.

Berorientasi pada kesimpulan diatas peneliti juga mengakui adanya keterbatasan dalam penelitian seperti data yang digunakan dalam penelitian masih terbatas pada PDB, tenaga kerja, pendanaan dan UMKM. Untuk peneliti selanjutnya diharapkan dapat melengkapi data yang dapat mempengaruhi suatu negara mengalami resesi seperti data ekspor-impor, produksi-konsumsi, inflasi-deflasi dan data lainnya yang dapat mendukung penelitian sehingga lebih dapat memetakan strategi yang tepat untuk menghadapi ancaman resesi.

\section{DAFTAR PUSTAKA}

A. O'Sullivan. (2003). Economics: Principles in action. Pearson Prentice.

Aulawi, A. (2020). Penerbitan Peraturan Pemerintah Pengganti Undang-Undang Nomor 1 Tahun 2020 Sebagai Strategi Kebijakan Pajak Pemerintah Indonesia Dalam Menghadapi Dampak Pandemi Covid-19 Terhadap Keuangan Negara. Progress: Jurnal Pendidikan, Akuntansi Dan Keuangan, 3(2), 110-132. https://doi.org/10.47080/progress.v3i2.936

Ayu, F., \& Haryati, D. (2020). Strategi Kebijakan Fiskal Terhadap Output dan Inflasi Pada Perekonomian Indonesia dalam Menghadapi Dampak Virus Covid-19. Business Innovation and Entrepreneurship Journal, 2(3). https://doi.org/2684-8945

Badan Pusat Statistik. (2020). Ekonomi Indonesia Triwulan II 2020. Bps. Go.Id, 7-8.

Berapa Jumlah UMKM di Indonesia? Ini Hitungannya. (2020). Liputan6.Com. https://www.liputan6.com/bisnis/read/4346352/berapa-jumlah-umkm-di-indonesiaini-hitungannya\#: : text=Menurut Badan Pusat Statistik (BPS, usaha yang beroperasi di Indonesia.

Daud, D. (2020). Social Distancing dan Budaya Kita. Pandemik COVID-19 Persoalan Dan Refleksi, May, 39-47. 
E.P Saputro. (2020). Digitalisasi Koperasi. Analisis.Kontan.Co.Id. https://analisis.kontan.co.id/news/digitalisasi -koperasi

Faroni, C., Marcellino, M., \& D, S. (2020). Forecasting The Covid-19 Recession and Recovery: Lessons from The Financial Crisis (No. 2468).

Feranika, A., \& Haryati, D. (2020). Strategi Kebijakan Fiskal Terhadap Output dan Inflasi pada Perekonomian Indonesia dalam Menghadapi Dampak Virus Covid 19. Business Innovation and Entrepreneurship Journal, 2(3), 146-152.

Hasibuan, G. L., Dermawan, D., Ginting, H., \& Muda, I. (2020). Allocation of COVID-19 Epidemic Funding Budgets in Indonesia. Journal of Research and Review, 7(5).

Kautsar, A., \& Krisnadi, I. (2020). Digitalisasi Koperasi dalam Penyempurnaan Konsep Pasar Digital Nasional sebagai Penangkal Resesi Ekonomi di Masa Pandemi Covid-19.

Kompas.com. (2020). Bersiap Menghadapi Puncak Pandemi Covid-19 di Indonesia Halaman all - Kompas.com. 29 April 2020.

Liputan6.com. (2020). Sri Mulyani: Corona Beri 3 Dampak Besar ke Ekonomi Indonesia Bisnis Liputan6. com. 30 Juni 2020.

Mahera, N., \& Nurwati, N. (2020). (PDF) KRISIS EKONOMI DI INDONESIA DISEBABKAN OLEH PANDEMI COVID-19. April 2020.

Marlinah, L. (2020). Peluang dan Tantangan UMKM Dalam Upaya Memperkuat Perekonomian Nasional Tahun 2020 Ditengah Pandemi Covid 19. Ekonomi, 22(2).

Miraza, B. H. (2019). Seputar Resesi dan Depresi. Seputar Resesi Dan...\{Miraza\}| 11 Jurnal Ekonomi KIAT, 30(2), 11-13.

Moedjiono, A. W. (2020). Sejarah Panjang Virus Korona - Kompas.id. 8 April 2020.

Nafiah, B., Anggara, R., Balapradhana, A., \& Eko, W. (2020). Antisipasi Resesi dan Krisis Pangan Akibat Pandemi (Seri II). Syiah Kuala University Press.

Naryono, E. (2020). Impact Of National Disaster Covid-19 Indonesia Towards Economic Recession. Stie Pasim Sukabumi.

Nasution, D. A. D., Erlina, E., \& Muda, I. (2020). Dampak Pandemi COVID-19 terhadap Perekonomian Indonesia. Jurnal Benefita, 5(2), 212. https://doi.org/10.22216/jbe.v5i2.5313

Salim, H. (2020). [Update] Data Investasi Startup di Indonesia Tahun 2019-2020| HalloJatim.com - Portal Berita Jawa Timur.

Sugiyono. (2014). Metode Penelitian Pendidikan Pendekatan Kuantitatif, Kualitatid Dan R\&D. Alfabeta.

Sulkowski, L. (2020). Covid-19 Pandemic; Recession, Virtual Revolution Leadingto Deglobalization? Journal of Intercultural Management, 12(1), 1-11.

Tim Infografis. (2020). Grafik Data Kenaikan Kasus Corona di RI, Per 21 April 2020. 22 April 2020.

Undang-undang Republik Indonesia Nomor 20 Tahun 2008 tentang usaha mikro, kecil, dan menengah. 